\title{
IDENTITY AND THE DIVERGENCE OF DISCOURSES IN CROATIA AND EUROPE
}

\begin{abstract}
Siniša Rodin ${ }^{*}$
Summary: This paper explores the proposition that public discourse about the European Union in Croatia is not European, but national. The 'nationalness' of this discourse about Europe leads to divergent constructions of Croatian and European identity, and this, in turn, makes inclusion in the EU's distributive mechanisms more difficult. The first part of the paper highlights the two discourses that exist in Europe - European and national. The second part describes how Croatian and European public discourse about the European Union diverge, and what the consequences of this divergence are. In the third part, reasons contributing to this divergence are offered, and the dangers of such a development for Croatia's European future are indicated.
\end{abstract}

Approximately one year ago, speaking at the University of Regensburg, Wojciech Sadurski ${ }^{1}$ highlighted a distinction, originally introduced by Bernard Williams, ${ }^{2}$ between 'real' and 'notional' confrontation:

A confrontation is 'real' rather than merely notional when an outlook of another group is a real option for us. This means that becoming like them is reasonably plausible or feasible. It is not just comparing ourselves to a culture or an identity which we, in real life, cannot resemble anyway, but rather we are confronting a culture with a practical implication behind it. ${ }^{3}$

While Sadurski is referring to a real confrontation between European and US identity, I myself, as hinted in the Editorial Note to Vol II of this Yearbook, am inclined to see things from a different angle, invoking the split identity of the fictional Dr Jekyll and Mr Hyde from the novel by Robert Louis Stevenson. During the $20^{\text {th }}$ century, Europe has indeed developed a split identity which, on one side of the spectrum, is characterised by the two World Wars and the devastating experiences of

\footnotetext{
* Jean Monnet Professor, Faculty of Law of the University of Zagreb.

1 Wojciech Sadurski, 'European Constitutional Identity', paper presented at the $8^{\text {th }}$ International Congress on European Constitutional Law (Regensburg, 23-24 June 2006) (not yet published).

2 Bernard Williams, 'The Truth in Relativism' (1974-75) 75 Proceedings of the Aristotelian Society 215-28; Sadurski (n 1).

3 Sadurski (n 1) 7.
} 
Nazism and communism, while, on the other side, there is economic disarmament, market integration and, above all, the common experience of institution- and society-building. The process of identity-building in the European Union has produced an interesting phenomenon. In the absence of a united identity, national identities have confronted each other, typically resulting in armed conflict. At the same time, international law, being fluid as it is, was not a good opposite against which national identities could articulate themselves. However, as soon the identity of the European Community and its successor, the European Union, started to emerge, ${ }^{4}$ it provided a possible firm basis on which a real conflict could emerge. In that respect, Europe's identity is fundamentally different from the identity of the European Union. The former has been characterised by armed conflict, Nazism and communism, the latter by integration, cooperation, power-sharing, citizenship and tolerance..$^{5}$ In other words, the success of the European Union has created a risk of national identities being conceived not against Europe's negative historical experiences, but against the newly created identity of the European Union. If the European Union is to live up to the original idea of its founding fathers and preserve continental peace, I would suggest that the identity of a united Europe should not be constructed in confrontation to any external model, but rather in a real confrontation with its other, darker self. In any case, it is essential to avoid the danger of national identities being construed in opposition to the emerging identity of the European Union.

The principal proposition that I explore in this paper is that public discourse about the European Union in Croatia is not European, but national. It is the 'nationalness' of this discourse about Europe which leads to different constructions of Croatian and European identity, and this, in turn, makes inclusion in the EU's distributive mechanisms more difficult.

First, I highlight these two discourses - European and national that exist in Europe. Next, I describe how Croatian and European public discourse about the European Union diverge, and what some of the consequences of this divergence are. Then I offer some reasons which, to my understanding, have brought about such divergence. Finally, I explain the dangers of such a development for Croatia's European prospects.

\footnotetext{
4 Possibly starting from the landmark Van Gend en Loos case; see Case 26/62 NV Algemene Transport- en Expeditie Onderneming van Gend \& Loos v Netherlands Inland Revenue Administration [1963] ECR 1.

5 See eg Van Gend en Loos (n 4): 'The European Economic Community constitutes a new legal order of international law for the benefit of which the states have limited their sovereign rights, albeit within limited fields, and the subjects of which comprise not only the member states but also their nationals.'
} 


\section{The two discourses}

Before getting to the point, I should say that I understand "discourse on Europe" as a multitude of different communications that can be identified in politics, the media, science, and public life in general. In speaking about the two discourses - European and national - that generate a real confrontation, as defined by Williams, I do not imply that the former is present exclusively in the European Union or its Member States, and the latter exclusively in Croatia. On the contrary, both are found in the same space-time continuum, although not distributed evenly. Moreover, national discourse in Croatia seems to be not much different from national discourses in other European states. Having said this, I will start from Paul Feyerabend's position ${ }^{6}$ that it is not possible to say which one of these two discourses, the European or the national, is better; nor is it my aim to engage in such an exercise. I do contend, however, that one of these two distinct discourses is dominant in Croatia, while the other is not. As public discourse contributes decisively to the construction of identity, it is important to determine which one is dominant and understand in which direction is it developing. Here I will present some examples.

In Croatia, there is a longstanding and widespread conviction that Croatian identity has always been European, due to Croatia's always having been an integral part of European territory, and that membership in the European Union cannot make any difference in this respect. By this same token, Croatia's European location, history and culture make any substantial reform unnecessary. We are Europe, with or without the EU. This understanding, although most frequently found in a political context, ${ }^{7}$ is not limited to political discourse, but can often be heard in debates on the reform of various institutions. In contrast to this position, Europe is defined not territorially, but through common values such as liberty, equality, and fundamental rights. ${ }^{8}$ Acceptance of and respect for European values has a central place, while territorial belonging to the European continent amounts to a necessary but not sufficient condition for EU membership.

\footnotetext{
6 Paul Feyerabend, Science in a Free Society (New Left Books, London 1978).

7 See eg speech by Prime Minister Ivo Sanader, speaking at a pre-election rally in Split on 12 May 2005: 'My answer to the question why am I so much in favour of the EU is: because Croatia has always been part of Europe. Croatia practices European values, and that has only to be formalised by accession.' <http://www.hdz.hr/wbs/w3b.exe/_hr/2/17/1456> accessed 20 September 2007.

8 See eg Art 6 TEU [2002] OJ C325/11: 'The Union is founded on the principles of liberty, democracy, respect for human rights and fundamental freedoms, and the rule of law, principles which are common to the Member States.'
} 
Furthermore, it is scarcely questioned in Croatia that the European Union restrains Member States in the exercise of their national sovereignty, which can ultimately lead to the loss of a barely acquired statehood. This contention neglects the well-established fact that the European Union acts via the agency of its Member States, and that national sovereignty is a condition for the functioning of the EU. Sovereignty is defined by the Member States' capacity to contribute towards achieving common goals (their place at the table), while the concept of national sovereignty as summa potestas, enshrined in the Croatian Constitution, ${ }^{9}$ is not jeopardised. On the contrary, Croatia, like any other Member State, will be in position to satisfy the obligations of membership only if it can fully exercise its national sovereignty. ${ }^{10}$ Also, as follows from earlier research, ${ }^{11}$ the voice of the Member States in the process of forming EU policies and, more generally, at the European and international level is better heard within the framework of EU membership than outside it. For example, Croatia's role in the CFSP has gradually increased from nonexistent to an exchange of information to the possibility of acceding to the CFSP Common Positions. Once it becomes a member of the EU, Croatia's voice will be heard at the common table.

Also, there is a widespread fear of foreign investment in Croatia. In public discourse this is reflected in statements to the effect that 'Croatia is being sold off to foreign investors'. The fear of imported goods is seen in statements denigrating 'cheap, low-quality imports', while the fear of migrant workers emerges in the form of active resentment and resistance and through the imposition of a variety of barriers, such as complicated procedures for mutual recognition of qualifications. And the fear of foreign services is reflected in statements such as 'There is a need for a genuinely Croatian bank', or the more populist slogan 'A Croatian wallet in a Croatian pocket'. These messages are in sharp contrast to the basic market freedoms on which the EU economy is based, and which are to be exercised regardless of national borders and without any discrimination based on nationality whatsoever.

\footnotetext{
9 Art 2 of the Croatian Constitution, consolidated text (2001) Official Gazette Narodne novine 41 .

10 For example, in order to be a member of the customs union, a Member State must ensure full control of its national borders. Failure to exercise this aspect of national sovereignty is an obstacle to membership.

11 In the context of Common Foreign and Security Policy, see S Rodin, 'Croatia' in Steven Blockmans and Adam Lazowski (eds), The European Union and its Neighbours: A legal appraisal of the EU's policies of stabilisation, partnership and integration (T.M.C. Asser Press, The Hague 2006) 357, 388; in the context of the free movement of persons, see I Goldner, 'Sloboda kretanja ljudi u Europskoj uniji temeljem Europskih sporazuma i Sporazuma o stabilizaciji i pridruživanju', doctoral dissertation (Faculty of Law, Zagreb, 2005).
} 
Furthermore, in Croatia there is widespread public acceptance of special interests that are understood as being national. This has led to an entire normative system of social privileges reserved for nationally defined social groups, such as, for example, Croatian artists being entitled to free pension and medical insurance, Croatian pensioners being entitled to subsidised pensions, the children of Croatian veterans being allowed direct university enrolment, regardless of the numerus clausus, and so on. Favouring national interests in the economy is likewise seen as justified. For example, a recent study by the Faculty of Transport of the University of Zagreb, produced for the Ministry of the Sea, Tourism, Transport and Development, proposed direct discrimination against foreign truck drivers, who would be stopped at the state border during certain hours, while national truckers would be admitted into the country. ${ }^{12}$ The study emphasises that 'the state authorities, ie the inspection services, must serve to enhance the competitiveness of Croatian truckers'. Again, this represents a U-turn from the European standard, defined by the elimination of discrimination based on nationality and the prohibition of distinctly applicable measures. ${ }^{13}$

\section{The divergence of discourses and its consequences}

These examples bear witness to the divergence of Croatian national and European discourses on key points concerning the creation of European identity: sovereignty, market freedoms, and non-discrimination. This divergence has had several consequences, as follows.

Probably the easiest one to detect is the phenomenon I call semantic dissonance. In diverging discourses, the same words are ascribed a different meaning, making communication more difficult. The same language is applied to different concepts, and so we do not understand each other.

Secondly, and more importantly, divergence affects the construction of identity. National identity is not conceived in contrast to negative historical experiences, but rather in contrast to European identity. Negative historical experiences are often brushed aside, ${ }^{14}$ while certain

12 'Hrvatska treba zabraniti ulazak kamiona nedjeljom do 20 sati - Fakultet prometnih znanosti predlaže sprječavanje ulaza strancima s ekološki neprihvatljivim vozilima' ['Croatia should prohibit entry of trucks on Sundays till 8 pm - Faculty of Transport proposes blocking entry for foreigners driving ecologically unacceptable vehicles'] Poslouni dnevnik (12 February 2007).

13 See eg Case C-147/03 Commission v Austria, for an infringement of Community law due to discrimination on the grounds of nationality.

14 See eg the web page of the Croatian Administrative Court <www.upravnisudrh.hr> accessed 20 September 2007: 'The Administrative Court, as an independent court of the Republic, was established on 1 July 1977. Before then, judicial review of the legality of indi- 
social phenomena and moral standards are denigrated as being imported from Europe and opposed to what are understood as 'genuine national values'. Examples of this abound, including attitudes towards the market freedoms, the family, sexual minorities, foreigners, pluralism, and so on.

Unlike Croatian national identity, which is conceived, at least in part, as opposed to European values, European identity is defined in contrast to the negative historical experiences of Nazism and communism, and to the identity of individual Member States. This can be traced back to the very outset of European integration, as is well documented by the Schumann Declaration. ${ }^{15}$ Today, more than fifty years later, during which time Europe has grown into a continental public order, the same idea has been expressed by Marek Cichocki, Poland's representative for drafting the EU's 50th anniversary declaration. ${ }^{16}$ Europe must be conceived not only in contrast to Nazism, but also to communism and to Balkan-style nationalism. Certainly, European identity is not in competition with the identity of the Member States, but rather is construed as added value on top of national identity. ${ }^{17}$ This can be understood well from the landmark Nold case, where the European Court of Justice asserted that in protecting fundamental rights it was "bound to draw inspiration from constitutional traditions common to the Member States, and [...] cannot therefore uphold measures which are incompatible with fundamental rights recognised and protected by the constitutions of those States'. ${ }^{18}$

The third consequence of diverging discourses can be described as institutional impotence. Croatia's institutions have remained or become unable to create policies that could form part of broader European objectives. The political system and its institutions are incapable of generating

vidual final administrative acts was overseen by the Administrative Division of the Supreme Court of the Republic of Croatia. It is important to mention that there is a long tradition of administrative justice in the territory of the Republic of Croatia. Administrative jurisdiction can be traced back to the second half of the 19th century.' It is worth noting that the highest judicial instance in Croatia in 1977 was not the Supreme Court of the Republic of Croatia, but rather the Supreme Court of the Socialist Republic of Croatia. This fact is ignored for the purpose of continuity in constructing institutional identity.

15 The solidarity in production thus established makes it plain that any war between France and Germany would be not merely unthinkable, but materially impossible.

16 Andrew Rettman, 'Poland to push for "dark" side to EU birthday text' EUobserver (22 February 2007): 'It shouldn't simply be a self-celebration by the old member states. It should include our part of Europe as a parallel process experienced after WWII. It should also make mention of the dark legacy of European policy. During the great successes of extending the European Union in the 1990s, we had parallel to that a serious war in the Balkans' <www. euobserver.com> accessed 23 February 2007.

17 See Art 2 TEU: 'The Union shall respect the national identities of its Member States.'

18 Case 4/73 J. Nold, Kohlen- und Baustoffgroßhandlung $v$ Commission [1974] ECR 491. 
decisions that comply with European standards, ${ }^{19}$ as manifested in the 'crisis of the judiciary', 'inefficient public administration' or 'corruption'. As institutions are unable to anticipate acceptable outcomes for their activity, they often generate disparate results. One striking example is the misapplication of the requirements of the Bologna process in higher education and false adjustment to the European Qualifications Framework. The synergetic effect of Croatian legislation and sub-legislation is that a two-year university-level degree from Croatia is legally equivalent to a bachelor's degree from a European university, while a four-year Croatian bachelor's degree is equivalent to a European master's degree. ${ }^{20}$ Such degrees cannot obtain European recognition, while, on the other hand, they cause an inflation of Croatian bachelors and masters and degrade proper degrees earned in Europe. Also, laws are not infrequently introduced and then scrapped at once, due solely to reaction from the European side. ${ }^{21}$ Such institutional impotence is present not only in political institutions, but more generally in all spheres of public life.

Furthermore, the insufficient penetration of European topics into public discourse has created social differentiation between a participating minority which has access to European resources and a majority which is excluded. Such differentiation adds to the discontent of the excluded social group, creating a capillary obstruction of pro-European reforms. Generally speaking, resistance to reform is on the rise, and this phenomenon is only aggravated by the Croatian public's exclusion from the constitutional debate on the future of the EU. Another example of exclusion is the general absence of any debate on the Services Directive, despite the fact that tourist services make up a large part of Croatia's GDP. ${ }^{22}$ Certainly, the fact that Croatia is alone on its way to EU membership means that it is deprived of the unique experience of the enlargement debate and enlargement discourse.

19 J Habermas, Legitimationsprobleme im Staatkapitalismus (Suhrkamp, Frankfurt 1973).

20 See Art 14 of the Nacrt Prijedloga Zakona o akademskim i strucnim nazivima i akademskom stupnju [Draft Academic Qualifications Act] of August 2007, available on the Croatian Parliament's web page <http://www.sabor.hr/Default.aspx?art=15193\&sec=1220> accessed 21 September 2007.

21 For example, the recently scrapped law introduced to facilitate the construction of sports facilities for the World Handball Championship, which had to be revoked because it violated Community public procurement rules. Another example is the introduction of discriminatory registration charges for small boats, as introduced by the Naredba o visini naknade za upis broda, jahte i brodice u upisnik brodova, odnosno jahti i o evidnik brodica (2005) Official Gazette Narodne novine 41 and abrogated by the Naredba o izmjeni i dopuni Naredbe o visini naknade za upis broda, jahte i brodice u Upisnik brodova, odnosno jahti i o evidnik brodica (2006) Official Gazette Narodne novine 24.

22 Directive 2006/123/EC of the European Parliament and of the Council of 12 December 2006 on services in the internal market [2006] OJ L376/36. 


\section{Explaining the divergence}

I will offer two explanations as to why this divergence of discourses about Europe has occurred in Croatia: the re-legitimisation of the old political elite and the persistence of its traditional links with the economy; and a delay in the change of generations. Taken together, these phenomena have contributed to the survival of the old administrative elite.

First, it seems productive to refer here to the post-World War II British experience. It is a commonplace that Britain's economic fatigue in the 1950 s and 1960s had to do with its status as a victorious force and the persistence of traditional links between politics and the economy. ${ }^{23} \mathrm{Ow}$ ing to this, traditional industries were able to survive thanks to political protectionism, despite their lack of competitiveness. Similarly, Croatia, having won the war for independence, has continued to protect non-competitive industries, regardless of whether these are privatised (eg food processing) or state-owned (eg shipbuilding). Instead of restructuring under the pressure of market forces, entire industries have sought protection in the political elite, which has not been de-legitimised like those in other post-communist states, but rather has acquired a new legitimacy based on the concept of national reconciliation. ${ }^{24}$ In other words, privatisation was arranged by the old social elite, which partly transformed itself into the nouveaux riches and partly entered into practical interest arrangements with the new capitalist class. In this way, the old political elite, invigorated by the new national legitimacy, has 'protected' Croatia's 'national capital' from internationalisation, that is, from the acceptance of European free market principles. ${ }^{25}$

The second explanation for the divergence of discourses is a delayed change of generations. As I have already pointed out, one of the main problems slowing down Croatia's entry into the European mainstream is that Croatian identity is not conceived against the negative historical ex-

23 Neil Rollings, 'British Industry and European Integration 1961-1973: From First Application to Final Membership' (1998) 27 Business and Economic History 2, 444.

24 See eg Silvana Oruč Ivoš, 'Umjesto mladih stranke nude potrošene političare' ['Instead of young people, parties offer worn-out politicians'] Vjesnik (26 February 2007) 5. Political analyst Davor Gjenero supports this view, explaining that 'after four electoral cycles it would be reasonable to expect that major shifts of generations would occur in certain political parties. Nothing like this has happened. In 2000 we did not have a single public figure on the political scene who was not already an important political figure before then; that is, we did not have any new political figures.' National reconciliation of the left and right was one of the main aims of the late President Tuđman, who was himself a converted member of the Communist Party.

25 Social Democrat MP Neven Mimica, speaking before the Croatian Parliament's European Integration Committee, warned against Croatia's slowness in harmonising its law with the acquis on 17 February 2007. At the present pace, Croatian law will not be harmonised with the acquis before 2019. <http://bosna.odisej.hr/magazin/vijesti/vijesti2006. asp?vijest=1003> accessed 20 September 2007. 
periences of Nazism and communism, but rather against European identity, and so, for that reason, European standards are understood not as originally Croatian, but as something 'imposed' from outside. Such a construction of national identity has had a decisive impact on the conditions of reproduction of the social elite. The change of generations in Croatia either did not occur or, where it did, was controlled by the old social elites who were able to invest in their own successors. Examples of this can be found in public television, the judiciary, science, and education. Such conditions of social transition are not incidental, but rather result from a carefully designed regulatory policy. For example, the Courts Act provides that, in order to qualify for the position of judge on the High Commercial Court or Administrative Court, a candidate must have at least 8 years of practice as a judge, or at least 12 years of working experience as an attorney, professor of law, or public notary; judges of the Supreme Court must meet a 15-year requirement. ${ }^{26}$ It is absolutely clear that even today (not to mention the 1990s) such requirements could only be satisfied by persons who acquired their legal education under communism. One might wonder whether this reliance on traditional socialist legal education has contributed to the crisis of the judiciary and public administration described repeatedly in reports by European institutions, which emphasise the need for their reform, including the reform of legal education. ${ }^{27}$

The survival and integration of the old administrative elite is also facilitated by various legislative arrangements. For example, Article 93 of the Law on Public Officials and Public Servants ${ }^{28}$ of 4 October 1994 provides that public officials need not pass the public service exam if they have at least 10 years of experience. This provision has enabled the sur-

\footnotetext{
${ }^{26}$ Article 75 of the Zakon o sudovima [Courts Act] (2005) Official Gazette Narodne novine 150 , incorporating earlier provisions.

27 According to the EUobserver (1 March 2007), '[t]he six-page draft Report of the European Parliament, prepared by Austrian socialist Hannes Swoboda, is particularly critical of Croatia's treatment of suspected war criminals as well as judicial and administrative reform'. <http://euobserver.com/?aid=23605> accessed 10 March 2007. See also EC Commission, 'Croatia 2006 Progress Report' (Commission Staff Working Document) COM (2006) 649 final: 'As regards professionalism and competence in the judiciary, there has been limited progress.' The need to reform the judiciary is also emphasised in the Negotiating Framework: 'In all areas of the acquis, Croatia must bring its institutions, management capacity and administrative and judicial systems up to Union standards with a view to implementing the acquis effectively or, as the case may be, being able to implement it effectively in good time before accession. At the general level, this requires a well-functioning and stable public administration built on an efficient and impartial civil service, and an independent and efficient judicial system.' European Council, 'Negotiating Framework: Principles governing the negotiations' (Luxembourg, 3 October 2005) <http://ec.europa. eu/enlargement/pdf/st20004_05_HR_framedoc_en.pdf> accessed 20 September 2007.

28 Zakon o državnim službenicima i namještenicima i o plaćama nositelja pravosudnih dužnosti (1994) Official Gazette Narodne novine 74.
} 
vival of public servants employed after 1984. Therefore, involvement in pre-democratic institutions is not only not an obstacle, but even a recommendation for appointment to the highest public offices. No wonder one Member of Parliament recently remarked, with regard to a possible appointee for the position of Constitutional Court judge, that the candidate was 'an excellent lawyer, and already a judge of the Constitutional Court during the former Yugoslavia'. ${ }^{29}$

However, it is still possible to observe a difference between institutions that Croatia 'inherited' from socialist Yugoslavia, such as its courts of law, some ministries, or its universities, and institutions that have been newly created for specific purposes of modernisation and Europeanisation, such as the Croatian Competition Agency, the State Commission for Public Procurement Control, and others. By necessity, these new institutions have had to employ younger, better-qualified public servants.

The difference between 'old-style' and 'new-style' institutions and the dynamics of their relationship are nicely illustrated by a recent judgment of the Croatian Administrative Court, ${ }^{30}$ annulling a decision by the Croatian Competition Agency. The Agency, with reference to Community competition rules applicable pursuant to Article 70 of the Stabilisation Agreement, had declared a vertical distribution agreement illegal. According to the Administrative Court judgment, however, 'the criteria, standards and instruments of the European Communities to which the Agency refers are not contained in the text of the [Stabilisation and Association] Agreement, and are not transposed or published in any other Croatian law or act, and therefore cannot be a source of law'. Without entering into a more detailed legal analysis of this judgment, suffice it to say that the Agency, by applying the interpretative standards of Community law, had reached one conclusion, while the Administrative Court, excluding those standards, had reached the opposite one.

The persistence of the 'old cadre' is not exclusive to the judiciary and public service. For instance, the Museums Act ${ }^{31}$ lists the requirements that must be satisfied by a museum director, including a university diploma and the state exam. Exceptionally, however, a person without the required qualifications but with 10 years' experience may be appointed. In other words, work experience can substitute for a university degree.

At the same time, integration of the up-and-coming generation of young professionals, educated at European and American universities, is

\footnotetext{
29 N Božić, A Plišić, 'Mogao bih biti potpredsjednik Vlade ili sudac Ustavnog suda' ['I could be deputy prime minister or a Constitutional Court judge'] Jutarnji list (12 March 2007).

30 Judgment of the Administrative Court No Us-5438/2003-7 of 26 October 2006 (2007) Official Gazette Narodne novine 16.

31 Zakon o muzejima (1998) Official Gazette Narodne novine 142.
} 
made excessively difficult by strict rules on the recognition of qualifications. The net effect of the Law on the Recognition of Foreign Qualifications $^{32}$ and the Science and Higher Education Act $^{33}$ is that the qualifications of students who have completed master's degree level studies in the European Union are granted the same value as those of students who have completed a four-year undergraduate programme in Croatia and other states of the former Yugoslavia. As a result, master's degrees from the most prestigious universities in Europe are formally equated with four-year bachelor's degrees from any university in the former Yugoslavia. Such legislative policy discourages study abroad and makes the integration of returning students more difficult.

In brief, for the reasons stated above, European discourse in Croatia is channelled through unreformed institutions and thus muted or wrongly interpreted, generating a semantic dissonance. For example, the perception of Europe is formed via discourse on the International Criminal Tribunal for the Former Yugoslavia, and not on European reform, enlargement, institutions, or values. Another phenomenon is the projection of certain local issues as European ones, for example, the border dispute with Slovenia or the question of the esuli (post-WWII Italian refugees from Yugoslavia). Such issues do not form part of European identity; on the contrary, they represent its dark side, against which European discourse should be constructed.

\section{Conclusion}

The first wave of transition in Croatian society did not take place in an environment of European discourse. As a consequence, it did not bring about a Europeanisation of Croatia's institutions and Croatian society in general. The change of generations has occurred only partially, and in such a way as to enable functional integration into the European mainstream under conditions predominantly dictated by the communist and post-communist elites. Today the change of generations is complete; yet it has not brought about a Europeanisation of Croatian institutions, but rather a perpetuation of national discourse.

In such circumstances, the key question is not when Croatia will join the EU, but rather whether, at the moment of accession, Croatian society will be capable of taking part in mainstream European discourse and thereby maximising the benefits of membership. At the moment, no

\footnotetext{
32 Zakon o priznavanju inozemnih obrazovnih kvalifikacija (2003) Official Gazette Narodne novine 158, as amended by the Zakon o izmjenama i dopunama Zakona o priznavanju inozemnih obrazovnih kvalifikacija, (2006) Official Gazette Narodne novine 138.

33 Zakon o znanstvenoj djelatnosti i visokom obrazovanju (2003) Official Gazette Narodne novine 123 , as amended.
} 
such capacity is evident. Unless Croatian society becomes capable of absorbing the positive redistributive effects of prospective membership, the frustration generated by its reduced ability to utilise the benefits of the pre-accession period may lead to public opinion turning against EU membership. 